\title{
Assessment and Monitoring of Fish Species in the Mountain Streams and Lake of Mindanao LTER Sites
}

\author{
VICTORIA T. QUIMPANG \\ ORCID No. 0000-0003-1992-6359 \\ vtquimpang.orcid@gmail.com \\ Biology Department, College of Arts and Science, Central Mindanao \\ University, Musuan, Bukidnon, Philippines \\ EINSTINE M. OPISO \\ ORCID No. 0000-0001-6806-4703 \\ einstineop@gmail.com \\ Geo-environmental Engineering Group, College of Engineering, Central \\ Mindanao University, Musuan, Bukidnon, Philippines
}

MARY CRIS CUDAL

ORCID No. 0000-0001-7644-2268

cudalmc@gmail.com

KATE LUCELLE COQUILLA

ORCID No. 0000-0003-4197-1236

klcoquilla.orcid@gmail.com

GLYNNE AIDETTE BUOT

ORCID No. 0000-0003-3703-9155

aunietes0812@gmail.com

RONALD REGAN C. FORTEN

ORCID No. 0000-0002-7480-8374

rrforten.orcid@gmail.com 


\title{
ANGELA GRACE T. BRUNO \\ ORCID No. 0000-0003-4941-8232 \\ agbruno.orcid@gmail.com
}

Environmental Sciences Department, College of Forestry and Environmental Science, Central Mindanao University, Musuan, Bukidnon, Philippines

\section{VICTOR B. AMOROSO}

ORCID No. 0000-0001-8865-5551

victoramoroso@gmail.com

Center for Biodiversity Research and Extension in Mindanao, Central

Mindanao University, Musuan, Bukidnon, Philippines

\begin{abstract}
Assessment and Monitoring on fish species was conducted in five (5) Longterm Ecological Research (LTER) sites in Mindanao, Philippines. These LTER sites were Mt. Apo in North Cotabato, Mt. Hamiguitan in Davao Oriental, Mt. Kitanglad and Mt. Musuan in Bukidnon, and Mt. Malindang in Misamis Occidental. Streams and Lakes of these sites were sampled to assess the fish species found in each sites and its significance in the aquatic ecosystem. There were 13 fish families found from the five LTER sites. One endemic species Puntius bantolanensis was found only in two mountain sites Mt. Apo and Mt. Hamiguitan. Ten native species were distributed among all sites. Seven were unclassified for its occurrence. Out of the 34 species, 15 were introduced. However, these introduced species have only diminutive individual counts per site of which they occur. The study revealed that Mindanao streams were composed of diverse fish species. Endemic and native fish species has the need to be protected and ecosystem must be conserved. Some introduced fish species are invasive and that might disturb and affect aquatic ecosystem. Bray Curtis cluster analysis reveals that Mt. Musuan and Mt. Malindang shows similarity of species. Mt. Kitanglad has the least similar species compared to the other four mountains. Some physico-chemical characteristics vary from each stream in all sites and somehow affect presence of fishes.
\end{abstract}

Keywords: aquatic ecosystem, freshwater fishes, water quality, endemic, native 


\section{INTRODUCTION}

The Philippines is biologically unique as it harbors endemic plants and animals in the country's islands and ecosystems and home to some of the most endangered species and habitats in the world. However, the remaining forest which are the home of these endemic plants and animals in the country are at risk due to rapid rate of decrease in forest cover caused by slash and burn farming, logging, mining and quarrying. These activities are continuing even in established Long-Term Ecological Research (LTER) sites in the Philippines because of lack of information and awareness and the political will with regards to the protection and conservation of the biological resources. Anent to this, one of the components of the LTER sites that will be severely affected is the aquatic ecosystems. Such problems will then result to frequent occurrences of riverine flooding and landslides within the watersheds of the LTER sites and therefore enhance soil erosion, bacterial and chemical contamination and variation in stream discharge patterns. As a result, some of these important flora and fauna in the aquatic ecosystems may be lost before we knew their existence and status. Hence, these conditions make Philippines as one of the world's biodiversity hotspots (Myers et al. 2000).

Fish as a top predator in aquatic food web plays a role in determining the ecological status of water bodies. According to Jackson (2003), the presence or absence of fish can affect whether other species are able to utilize river or stream habitats. Freshwater fish assessment provides information about their community, structure and composition. It will also give an update of new list of freshwater fish found in the area. On the other hand, freshwater fish all over the world include approximately 170 families, 2,500 genera representing from 13,000 species (Leveque et al. 2008). According to Fishbase 2013, 321 freshwater fish species are listed in the Philippine. Many unique freshwater fish species, particularly gobies, pipefish and halfbeaks are known to be restricted only to isolated lakes and rivers in major islands in the Philippines.

Although there were numerous studiesdone worldwide on freshwater fishes, only few studies have been conducted in Mindanao, Philippines. The lack of concern of freshwater fish is possibly due to the overall proximity of terrestrial and marine environment around the archipelago which attracted more attention from scientist and other researches. Moreover, the current status in these beleaguered freshwater habitats particularly in Mindanao LTER sites is not yet known. Thus, this study provides additional knowledge to identify those species most in need of conservation interventions. 


\section{OBJECTIVES OF THE STUDY}

This study focused on the assessment, and monitoring of fishes in five Mindanao LTER sites which include Mt. Apo in North Cotabato, Mt. Hamiguitan in Davao Oriental, Mt. Kitanglad and Mt. Musuan in Bukidnon, and Mt. Malindang in Misamis Occidental. The assessment and monitoring were conducted in order to determine the abundance, distribution and species composition of the fish habitats in the selected LTER sites. The water quality of the selected rivers, streams and lake were also assessed.

\section{MATERIALS AND METHODS}

\section{Study Sites}

The study was carried out at mountainous streams, rivers and lake found on five LTER sites of Mindanao (Fig. 1):Mt. Musuan of Bukidnon Province had an elevation of 646 meters above sea level. It is located in Musuan, Dologon, Maramag, Bukidnon. According to Philippine Institute of Volcanology and Seismology (PHIVOLCS), it is an active volcano which last erupted in 1866 and 1867. The Mt. Musuan serves as watershed from Brgy. Kibulawan and Brgy. Liloan of Lumbo, Valencia City and will deposit to Pulangui river; Mt. Kitanglad in Lantapan Bukidnon had an elevation of 2,938 masl and considered being one of the highest mountain range in Mindanao. Its major watershed provides water for irrigation, power generation and domestic use for Bukidnon province as well as the province of Misamis Oriental, and the catchment area of Cagayan, Tagoloan and Pulangui river system; The famous Mt. Apo of Kidapawan city in the Province of North Cotabato, the highest mountain in Mindanao. Mt. Apo is the watershed of over 19 river systems located in Davao City, Davao del Sur, Bukidnon and Cotabato; Mt. Hamiguitan Range located on the south eastern side of Davao Oriental is the headwaters of different rivers and creeks which one of these rivers provides water for domestic use and irrigation in the lowland area of the municipality of Governor Generoso; Mt. Malindang situated at the center of Misamis Occidental Province. Within the area are: Crater Lake, the lake Duminagat, rainforest, mossy forest and pines and a large number of river system. Study areas of each mountain includes portion of forest, agroforestry areas, areas with human settlements and are prone to human disturbances and various anthropogenic activities. 


\section{Sampling}

At least 3 sampling stations were established with $100 \mathrm{~m}$ transect line based on the river and lakes' hydrology and human impact. The specific location of the station was determined by GPS. Numbers of sampling stations vary per mountain as well as number of river system sampled (Fig. 2). Fish collection was done by using various methods. Backpack electrofishing was done in fish collection on river; a medium pole seine net was used to catch immobilized fish. A 2 inch mesh gill net was used for sampling in the lake. Collected fishes were placed in a bucket of water and are handled with care to prevent water burn. All fishes caught were counted and initial identification was recorded. Fishes caught alive was released back in the water. Voucher of each species were obtained and was preserved with $10 \%$ formalin for further identification in the laboratory.

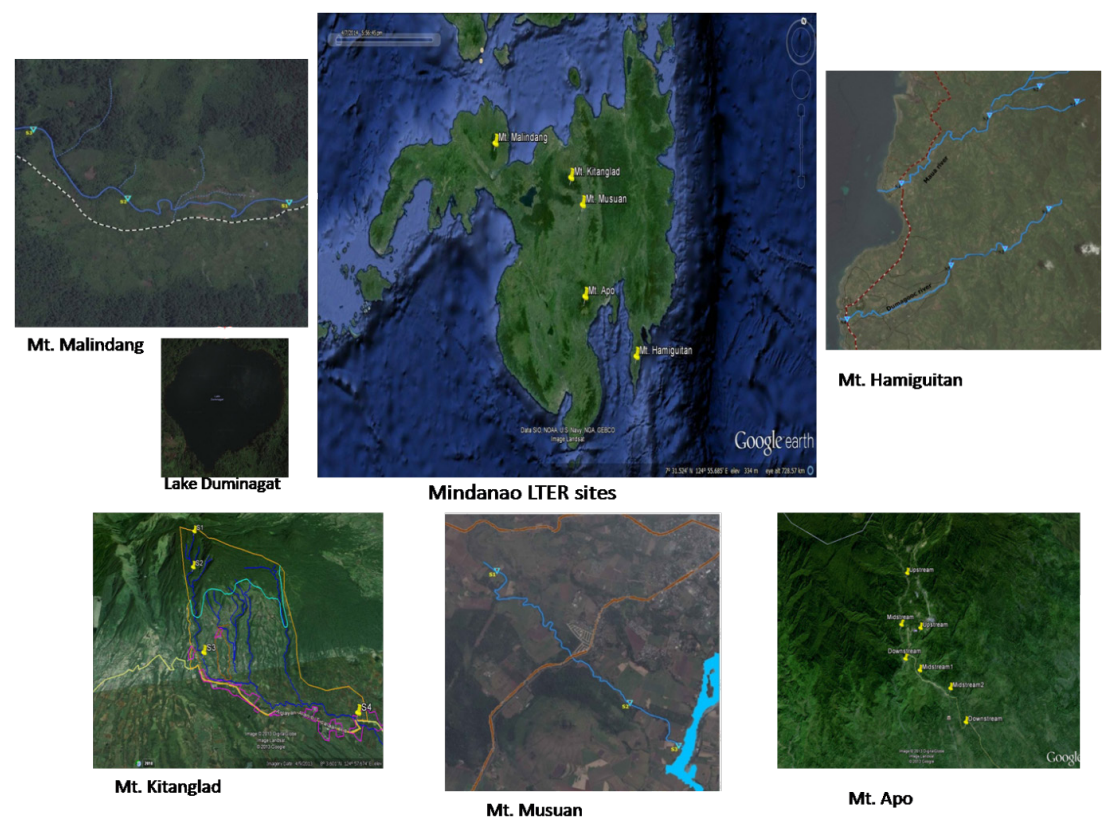

Figure 1. Map of Mindanao, Philippines showing the five (5) LTER sites. 


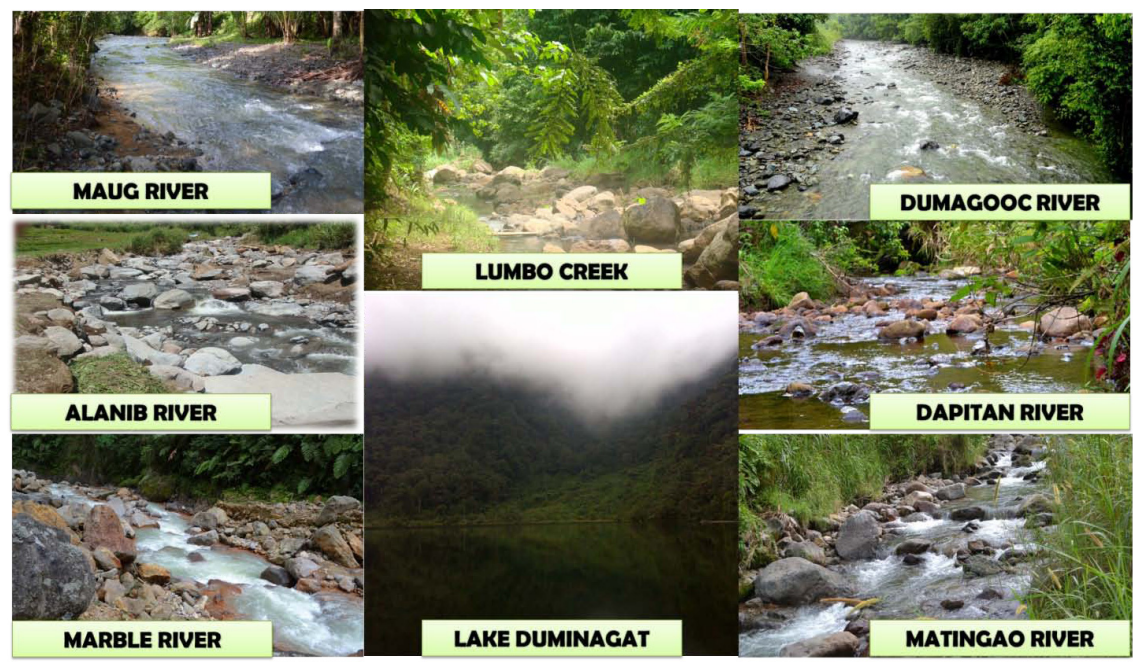

Figure 2. Some of the selected river stations in five Mindanao LTER sites

\section{Fish Morphometry, Description, and Identification}

Morphometrics of the fishes such as total length $(\mathrm{cm})$ and body weight $(\mathrm{g})$ was recorded. For total length $(\mathrm{cm})$, a ruler was used measuring from the tip of the fish snout closing it respectively up to the fish tail joining it respectively for fork tail shape. A weighing scale was used to get the body mass of the fish. Field description of the live fish was done by noting their color, number of fins, and barbells if present, shape of the tail and head, body structure and mouth. Species were then identified to species level using identification keys for Philippine freshwater fishes using primarily Fishbase 2013.

\section{Water Quality Test and Habitat Characterization of Aquatic Ecosystems}

Water quality test was done using multi-parameter probe (HORIBA U-52G). Dissolved oxygen (DO), $\mathrm{pH}$, turbidity, salinity, TDS, $\mathrm{pHmV}, \mathrm{ORPmV}, \mathrm{mS} / \mathrm{cm}$ and temperature were recorded. Details on water quality were used to determine habitat condition and correlation to presence of fish in the aquatic ecosystem. Water current and depth were also noted using measuring device and a meter stick as well as sedimentation rate on each sampling sites. Noting the presence of introduced species supports description and assessment on the disturbance of fish community and the impact on habitat of human activities modifying aquatic ecosystem. 


\section{Community Structure Analysis}

Fish individuals collected were counted according to species and families. Using BioDiversity Pro software version 2, species similarity across stations, Simpson Diversity Index, Abundance plot and Cluster Bray Curtis Analysis were determined from the samples.

\section{RESULTS AND DISCUSSION}

\section{Fish Composition}

A total of 838 individuals were collected in five mountains representing 34 species (including 5 unidentified) from 13 different families(Table 1;Plates 1 \& 2). Cyprinidae (51.1\%; percentages indicate the total abundance of each family per total individuals collected), Gobiidae (20.5\%), Clariidae (5.3\%), Poecillidae (8.0\%), Eleotridae (10.7\%), Anguillidae (8\%), Osphronomidae (1\%), Cichlidae (0.3\%), Ophicephalidae $(0.3 \%)$, Loricarridae $(0.3 \%)$, Anabantidae $(0.1 \%)$, Syngnathidae $(0.8 \%)$, Ophichthidae $(0.1 \%)$ and Unidentified $(0.1 \%)$ were the families with highest overall abundance (Fig. 2).

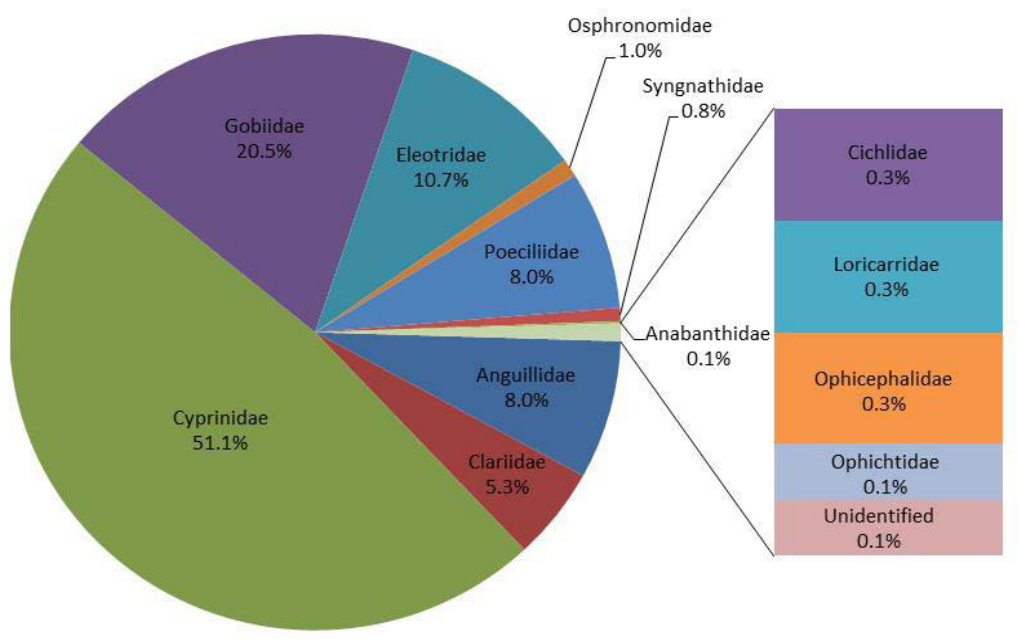

Figure 3. Fish families and percentage of individual counts in all mountain stream and lake sites (October 2012; January-November 2013). 
Table 1. Checklist of fish species from wade able streams and mountain lake throughout the five LTER sites in Mindanao (October 2012; January-November 2013)

\begin{tabular}{|c|c|c|c|c|c|c|c|c|c|}
\hline Family & $\begin{array}{l}\text { Scientific } \\
\text { Name }\end{array}$ & Occurrence & $\begin{array}{l}\text { Common } \\
\text { Name }\end{array}$ & $\begin{array}{l}\stackrel{\circ}{<} \\
\stackrel{\dot{L}}{\Sigma}\end{array}$ & 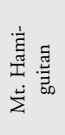 & 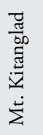 & 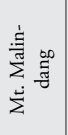 & 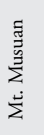 & 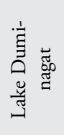 \\
\hline \multirow[t]{4}{*}{ Cyprinidae } & $\begin{array}{l}\text { 1. Puntius bantolanensis } \\
\text { (Day, 1914) } \\
\text { syn. Barbus bantolanensis } \\
\text { (Valenciennes, 1842) }\end{array}$ & endemic & Barb & $\mathrm{x}$ & $\mathrm{x}$ & & & & \\
\hline & $\begin{array}{l}\text { 2. Puntius binutatus (Valen- } \\
\text { ciennes, 1842) syn. Barbus } \\
\text { binutatus (Valenciennes, } \\
\text { 1842) }\end{array}$ & Native & $\begin{array}{l}\text { Line-spot- } \\
\text { ted barb }\end{array}$ & $\mathrm{x}$ & $\mathrm{x}$ & $\mathrm{x}$ & $\mathrm{x}$ & $\mathrm{x}$ & $\mathrm{x}$ \\
\hline & $\begin{array}{l}\text { 3. Cyprinus carpio carpio } \\
\text { (Linnaueus, 1758) }\end{array}$ & introduced & $\begin{array}{l}\text { Common } \\
\text { carp }\end{array}$ & & & & & & $\mathrm{x}$ \\
\hline & $\begin{array}{l}\text { 4.Chagunius chagunio } \\
\text { (Hamilton, 1822) }\end{array}$ & unclassified & Carp & & $\mathrm{x}$ & & & $\mathrm{x}$ & \\
\hline \multirow[t]{7}{*}{ Gobiidae } & $\begin{array}{l}\text { 1. Stiphodon atropurpureus } \\
\text { (Herre, 1927) }\end{array}$ & Native & $\begin{array}{l}\text { Blue neon } \\
\text { goby }\end{array}$ & & $\mathrm{x}$ & & & & \\
\hline & $\begin{array}{l}\text { 2.Sicryopterus micrurus } \\
\text { (Bleeker, 1853) }\end{array}$ & Native & $\begin{array}{l}\text { Cobalt blue } \\
\text { goby/ } \\
\text { Clinging } \\
\text { goby }\end{array}$ & & $\mathrm{x}$ & & & & \\
\hline & $\begin{array}{l}\text { 3.Sicryopterus lagocephalus } \\
\text { (Pallas, 1770) }\end{array}$ & Native & $\begin{array}{l}\text { Fork red- } \\
\text { tailed goby }\end{array}$ & & $\mathrm{x}$ & & & & \\
\hline & $\begin{array}{l}\text { 4.Sicryopterus lagocephalus } \\
\text { (Pallas, 1770) }\end{array}$ & Native & $\begin{array}{l}\text { Round } \\
\text { red-tailed } \\
\text { goby }\end{array}$ & $\mathrm{x}$ & $\mathrm{x}$ & $\mathrm{x}$ & & & \\
\hline & 5.Sicryopterus sp. 1 & unclassified & Goby & & $\mathrm{x}$ & & & & \\
\hline & 6. Sicryopterus sp. 2 & unclassified & Goby & & $\mathrm{x}$ & & & & \\
\hline & 7. Sicryopterus sp. 3 & unclassified & Goby & $\mathrm{x}$ & & & & & \\
\hline \multirow[t]{2}{*}{ Clariidae } & $\begin{array}{l}\text { 1.Clarias gariepinus } \\
\text { (Burchell, 1822) }\end{array}$ & introduced & $\begin{array}{l}\text { North } \\
\text { African } \\
\text { Catfish }\end{array}$ & & & & & $\mathrm{x}$ & \\
\hline & 2.Clarias sp. 2 & introduced & $\begin{array}{l}\text { North } \\
\text { African } \\
\text { Catfish }\end{array}$ & & & & & $\mathrm{x}$ & \\
\hline \multirow[t]{3}{*}{ Poecillidae } & $\begin{array}{l}\text { 1. Gambusia affinis } \\
\text { (Baird and Girard 1853) }\end{array}$ & introduced & Guppy & $\mathrm{x}$ & $\mathrm{x}$ & & $\mathrm{x}$ & $\mathrm{x}$ & \\
\hline & 2.Poecilia sp. & introduced & Guppy & $\mathrm{x}$ & $\mathrm{x}$ & & & $\mathrm{x}$ & \\
\hline & $\begin{array}{l}\text { 3.Xiphophorus helerii } \\
\text { (Heckel 1848) }\end{array}$ & introduced & $\begin{array}{l}\text { Swordtail } \\
\text { fish }\end{array}$ & $\mathrm{x}$ & & & $\mathrm{x}$ & & $\mathrm{x}$ \\
\hline
\end{tabular}




\begin{tabular}{|c|c|c|c|c|c|c|c|c|c|}
\hline & Xiphophorus sp.1 & introduced & Swordtail fish & & & & & & $\mathrm{x}$ \\
\hline & Xiphophorus sp. 2 & introduced & Swordtail fish & & & & $\mathrm{x}$ & & \\
\hline & Xiphophorus sp. 3 & introduced & Swordtail fish & & & & $\mathrm{x}$ & & \\
\hline & Xiphophorus sp. 4 & unclassified & Swordtail fish & $\mathrm{x}$ & & & & & \\
\hline Eleotridae & Oxyeleotris sp. & Native & Sleepy cod & & $\mathrm{x}$ & & & & \\
\hline & Oxyeleotris sp. 2 & Native & Sleepy cod & & $\mathrm{x}$ & & & & \\
\hline & Allomogurnda sp. & unclassified & Gurdeon & & $\mathrm{x}$ & & & & \\
\hline & Butis sp. & Native & $\begin{array}{l}\text { Sleeper/ } \\
\text { Gudgeon }\end{array}$ & & $\mathrm{x}$ & & & & \\
\hline & Mogurnda sp. & unclassified & Trout gurdeon & & $\mathrm{x}$ & & & & \\
\hline Anguillidae & $\begin{array}{l}\text { Anguilla mar- } \\
\text { morata } \\
\text { (Quoy and } \\
\text { Gaimard 1824) }\end{array}$ & Native & Mottled eel & & $\mathrm{x}$ & & $\mathrm{x}$ & & \\
\hline Ophichthidae & $\begin{array}{l}\text { Ophichthus apicalis } \\
\text { (Bennett 1830) }\end{array}$ & Native & $\begin{array}{l}\text { Bluntnose } \\
\text { snake eel }\end{array}$ & & $\mathrm{x}$ & & & & \\
\hline Osphronomidae & $\begin{array}{l}\text { 1. Trichogaster } \\
\text { trichopterus } \\
\text { (Pallas 1770) }\end{array}$ & introduced & $\begin{array}{l}\text { Three spot } \\
\text { gourami sp. } 1\end{array}$ & & & & & $\mathrm{x}$ & \\
\hline & 2. Trichogaster $s p .2$ & introduced & $\begin{array}{l}\text { Three spot } \\
\text { gourami } \\
\text { sp. } 2\end{array}$ & & & & & $\mathrm{x}$ & \\
\hline Cichlidae & $\begin{array}{l}\text { 1. Oreochromis } \\
\text { aureus } \\
\text { (Steindachner } \\
1864 \text { ) }\end{array}$ & introduced & Tilapia & & & & & $\mathrm{x}$ & \\
\hline Ophicephalidae & $\begin{array}{l}\text { 1. Ophicephalus } \\
\text { striatus } \\
\text { (Bloch 1793) }\end{array}$ & introduced & Striated murrel & & & & & $\mathrm{x}$ & \\
\hline Loricarridae & $\begin{array}{l}\text { 1. Pterygoplichthys } \\
\text { disjunctivus } \\
\text { (Weber 1991) }\end{array}$ & introduced & $\begin{array}{l}\text { Vermiculated } \\
\text { sailfin catfish; } \\
\text { janitor fish }\end{array}$ & & & & & $\mathrm{x}$ & \\
\hline Anabanthidae & $\begin{array}{l}\text { 1. Anabas testudin- } \\
\text { eus (Bloch 1792) }\end{array}$ & introduced & $\begin{array}{l}\text { Climbing } \\
\text { perch }\end{array}$ & & & & & $\mathrm{x}$ & \\
\hline Syngnathidae & $\begin{array}{l}\text { 1. Doryichtyes boaja } \\
\text { (Bleeker 1850) }\end{array}$ & Native & $\begin{array}{l}\text { Long snout } \\
\text { pipefish }\end{array}$ & & $\mathrm{x}$ & & & & \\
\hline Unidentified & & unidentified & & & $\mathrm{x}$ & & & & \\
\hline \multicolumn{4}{|c|}{ Total no. of fish individuals collected from each study sites: } & 153 & 373 & 12 & 106 & 153 & 41 \\
\hline \multicolumn{4}{|c|}{ Total no. of fish individuals in all LTER sites: 838} & & & & & & \\
\hline
\end{tabular}

*FishBase 2013 
The five (5) LTER sites showed diverse freshwater fish species. From 34 species in 13 different families, only one (1) endemic species Puntius bantolanensis was found in two LTER sites, Mt. Apo and Mt. Hamiguitan streams throughout the whole duration of the study; ten (10) native species were recorded includes Puntius binutatus, Stiphodon atropurpureus, Sicryopterus micrurus, Sicryopterus lagocephalus, Oxyeleotris sp., Oxyeleotris sp. 2, Butis sp., Anguilla marmorata, Ophichthus apicalis, and Doryichtyes boaja; fifteen (15) introduced species, Anabas testudineus, Pterygoplichthys disjunctivus, Ophicephalus striatus, Oreochromis aureus, Trichogaster sp. 2, Trichogaster trichopterus, Xiphophorus sp. 3, Xiphophorus sp.2, Xiphophorus sp.1, Xiphophorus helerii, Poecilia sp., Gambusia affinis, Clarias sp.2, Clarias gariepinus, Cyprinus carpio carpio; seven (7) unclassified, Chagunius chagunio, Allomogurnda sp., Mogurnda sp. three of it from family Gobiidae,Sicryopterus sp. 1 Sicryopterus sp. 2 Sicryopterus sp. 3, and one (1) species of family Poecillidae; and lastly, one unidentified species which was found in Mt. Hamiguitan only. A high count of endemic and native species implies healthy aquatic ecosystem such that endemic fish species are representative of local eco-environments for their high adaptation and dependence (He 2010), while native species are indicators of the health of aquatic ecosystems (Marin 2013). The endemic species P. bantolanensis was only collected in Mt. Apo and Hamiguitan which significantly dominated in fish individual counts in these two sites, therefore implies stable river ecosystem.

On the other hand, native fish species spread widely among the five LTER sites. Species of family Gobiidae, one of which is classified as native species are abundant in Mt. Hamiguitan, Mt. Kitanglad and Mt. Apo streams. Gobiidae species is among the most structurally diverse and numerically specious fish families in the world (Miller 1986). Many goby species exhibit amphidromy, they are swept out to the sea as larvae, but later return to rivers where they eventually become mature. As cited by Tweedley et al. (2013) such migrations are particularly prevalent among species living on small and subtropical islands. Marine fishes Doryichtyes boaja and Ophichthus apicalis, are native species was found particularly in Mt. Hamiguitan streams (Dumagooc river).Such migration of these species from sea to river or vice versa is possible as the downstream part where these species were found is near the coastal area, hence outlet of the stream flows into the ocean.

Most of the fish species were classified as introduced fish species but each had only diminutive individual counts, however they may pose a threat to native and endemic fish species as well as disturbance to the river ecosystem. The species $G$. 
affinis, known as mosquito fish present in Mt. Malindang, Mt. Musuan and Mt. Apo was listed as one of Invasive Alien Species (IAS) in the Philippines (Joshi 2007). They are prolific breeders such that they are nicknamed as million fish which feeds on zooplankton and are found to be predating on eggs of fry of dojo in Banaue rice terraces, hatchlings of cyprinid loach and found to compete native fish. Introduced species can negatively impact native species and alter aquatic ecosystem. Impacts on aquatic biodiversity of introduced species falls into ecological and socio economic effects (Khan et al., 2011).

\section{Statistical Analysis}

On the basis of Bray- Curtis Cluster Analysis, Mt. Kitanglad has the least similar species compared to the other four mountains; it was discussed in the physico-chemical results that affect the species similarities between the icthyofauna of Mt. Kitanglad. Moreover the species similarity between Mt. Musuan and Mt. Malindang shows that the two mountains are more similar, while similarities of Mt. Apo compared to MtMusuan and Malindang are least similar, followed by Mt. Hamiguitan.

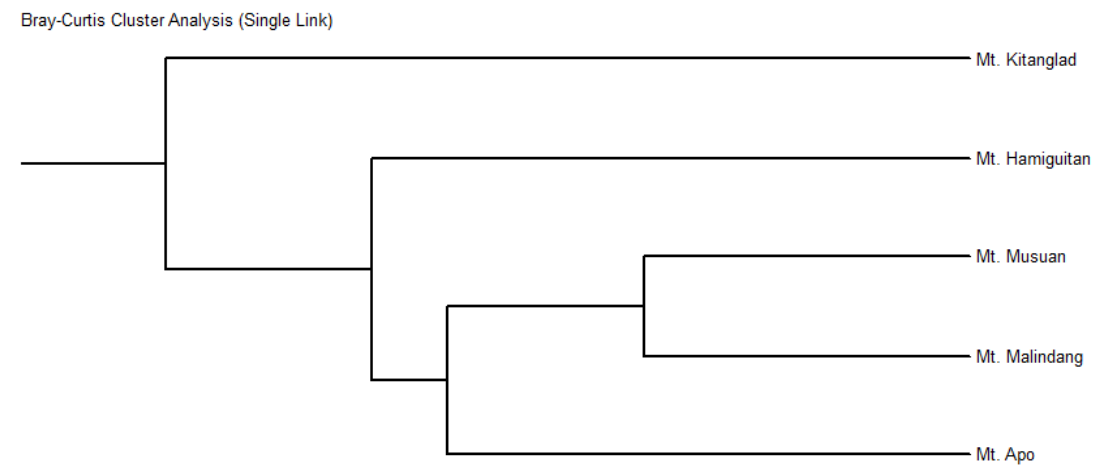

0. $\%$ Similarity

Figure 4. Bray- Curtis Analysis in five (5) Mindanao LTER mountain streams.

Table 2 below and Figure 4 below quantify the diversity of species present in each sites as well as the abundance of each species. Mt. Hamiguitan has high 
diversity followed by Mt. Apo, Mt. Musuan,Mt. Malindang and Mt. Kitanglad. The more species found, the higher the diversity will be observed.

Table 2. Simpsons Diversity Index in five (5) Mindanao

LTER mountain streams.

\begin{tabular}{|l|c|c|c|c|c|}
\hline \multicolumn{1}{|c|}{ Index } & Mt. Apo & $\begin{array}{c}\text { Mt. Hami- } \\
\text { guitan }\end{array}$ & $\begin{array}{c}\text { Mt. Kitan- } \\
\text { glad }\end{array}$ & $\begin{array}{c}\text { Mt. Malin- } \\
\text { dang }\end{array}$ & $\begin{array}{c}\text { Mt. Mu- } \\
\text { suan }\end{array}$ \\
\hline $\begin{array}{l}\text { Simpsons Diver- } \\
\text { sity (D) }\end{array}$ & 0.273 & 0.133 & 0.591 & 0.608 & 0.417 \\
\hline $\begin{array}{l}\text { Simpsons Di- } \\
\text { versity (1/D) }\end{array}$ & $\mathbf{3 . 6 6 6}$ & $\mathbf{7 . 5 0 1}$ & $\mathbf{1 . 6 9 2}$ & $\mathbf{1 . 6 4 4}$ & $\mathbf{2 . 3 9 7}$ \\
\hline
\end{tabular}

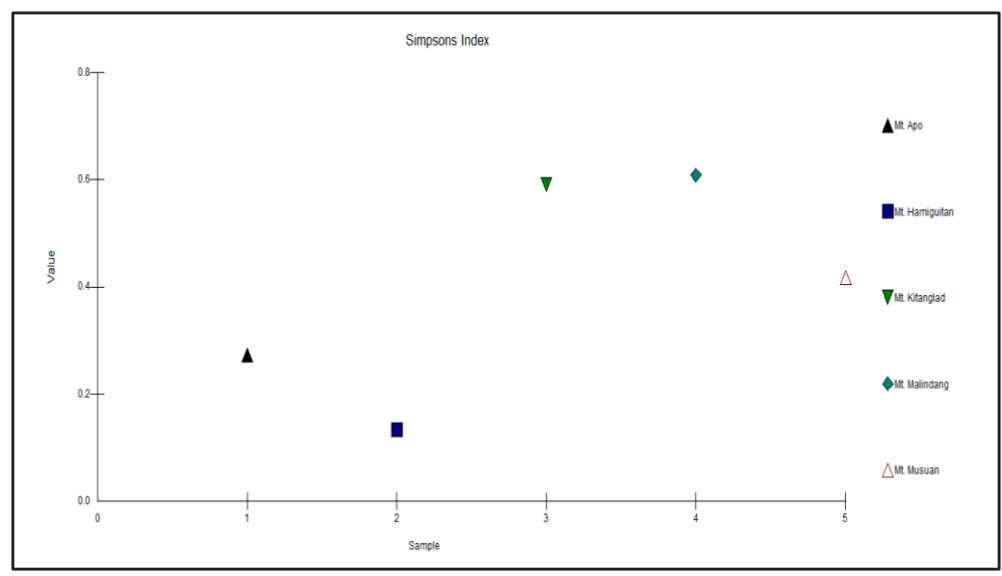

Figure 5. Simpson Diversity Index in five (5)

Mindanao LTER mountain streams. 


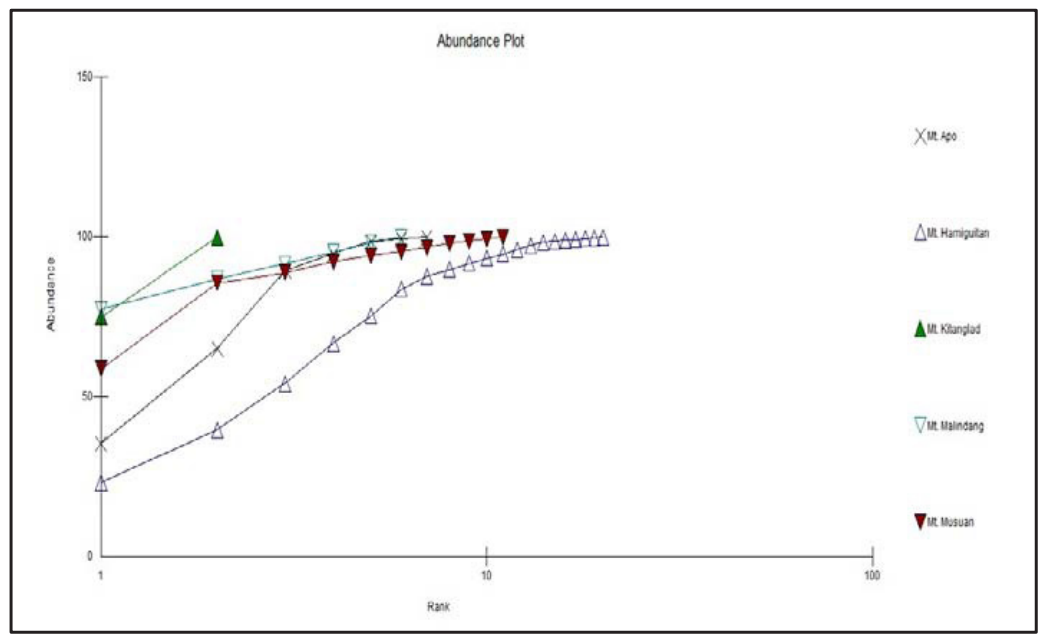

Figure 6. Abundance plot of the five (5) Mindanao LTER mountain streams.

The figure above indicates the abundance of species present in each mountainous site. Mt. Apo and Mt. Kitanglad shows possibility for discovering more species if another sampling will be conducted in the same area for further monitoring and new records of species. However, Mt. Hamiguitan and Mt. Musuan shows high tendency of abundance of species whether more sampling will be conducted, same species as from the previous sampling will still be collected. Otherwise if the curve of Mt. Musuan and Mt. Hamiguitan flatten out, no further sampling is needed. Mt. Malindang stream has the possibility of giving additional species if more sampling will be conducted.

Furthermore, Lake Duminagat was not included in the analysis for similarity and abundance considering it was the only lake sampled and the nature of the aquatic ecosystem differs from the rapid flowing riverine streams. Similarity of species from lake to the rivers and streams especially in the case of Dapitanriver. The lake outlet discharges water flowing into Dapitan river such that occurrence of same species in lake and river is possible.

\section{Effects of water quality variables on fish species composition}

Water quality indicators vary such that occurrence of fish species in each sites of sampling areas also vary as affected by the water quality variables (Figure 7). Of all the five (5) sites, only Mt. Kitanglad had diminutive number of fishes. 
Henceforth, Alanib River of Mt. Kitanglad exhibited the coldest and hottest water temperature of $13.75{ }^{\circ} \mathrm{C}$ and $24.71^{\circ} \mathrm{C}$ in upstream and downstream, respectively. Freshwater fish have optimum growing temperature in the range of $25-30^{\circ} \mathrm{C}$ (Kausar\& Salim,2006). Thus, fishes occur in the sites of the stream with high temperature. The diminutive number of fishes in Mt. Kitanglad is mainly due to the low temperature particularly in the upstream part of stream, in response, fish moved into more favourable areas of stream to regulate their body temperature.

On the other hand, Mt. Hamiguitan showed the highest fish individual caught among all five (5) LTER sites and having the most diverse fish species present. This indicates that the studied streams of Mt. Hamiguitan (Maug and Dumagooc) have favourable conditions for the survival, growth and reproduction of fishes. The streams also possess habitable temperature for fishes and showed an increasing trend of temperature from upstream to downstream and significantly within the range for optimum temperature for growth.

In the case of Matingao River at Mt. Apo, the variation of temperature is not significant even though the sampling sites differ greatly in elevation and land uses. The higher temperature in upstream of Matingao River is due to the mixing of hot water from Lake Agco into the stream water. Marble river of Mt. Apo reveals basic results of $\mathrm{pH}$, others are all acidic. This increasing trend of $\mathrm{pH}$ with decreasing elevation and distance travel by the river water from its headwater and their basic $\mathrm{pH}$ could be probably ascribed to the dissolution of ultramafic rocks which could significantly increase the $\mathrm{pH}$ of water. The lowest $\mathrm{pH}$ (6.39) recorded was in the upstream of the mentioned area. This observed acidity of river water during sampling was due to the release of acidic effluents from Energy Development Corporation (EDC) of Mt. Apo which is one of the biggest operating geothermal power plant in Mindanao. Like temperature and other variables, $\mathrm{pH}$ also affects the aquatic life in aquatic ecosystems. Alabaster and Lloyd (1980) as cited by Bryan 2004 identified the $\mathrm{pH}$ range that is not directly lethal to freshwater fish as 5.0-9.0. With few exceptions, $\mathrm{pH}$ values between 6.5 and 9.0 are satisfactory, on a long-term basis, for fish and other freshwater aquatic life. The $\mathrm{pH}$ of most inland freshwaters containing fish ranges from about 6 to 9 (Ellis 1937). Likewise, 6.5 below are poor and not favourable for the fish to survive. In case of Marble river, the presence of fish is mainly affected with the poor $\mathrm{pH}$ (6.39) of the stream. Other sites were generally at optimal range in terms of $\mathrm{pH}$.

DO levels has significant impact on the chemical processes and biological 
activity in aquatic ecosystems. In the selected rivers at Mindanao LTER sites, the amount of dissolved oxygen in water showed no significant variation between sampling sites (from upstream to downstream) and were above $10 \mathrm{mg} / \mathrm{L}$ except for the bottom part of Lake Duminagat in Mt. Malindang. The recorded DO values could support the favorable condition for fishes.

Turbidity of water among the sites was generally clear except for two sampling sites- the Marble River and the Matingaoriver in Mt. Apo. Marble River exhibits the highest turbidity especially at the upstream site which could be attributed to the release highly turbid and acidic effluents from a nearby geothermal power plant. This could be the reason why there were no fishes observed in the site since the highly turbid water could affect the sunlight penetration which could inhibit the photosynthesis process. This condition reduces available oxygen necessary for the fishes and other aquatic life.

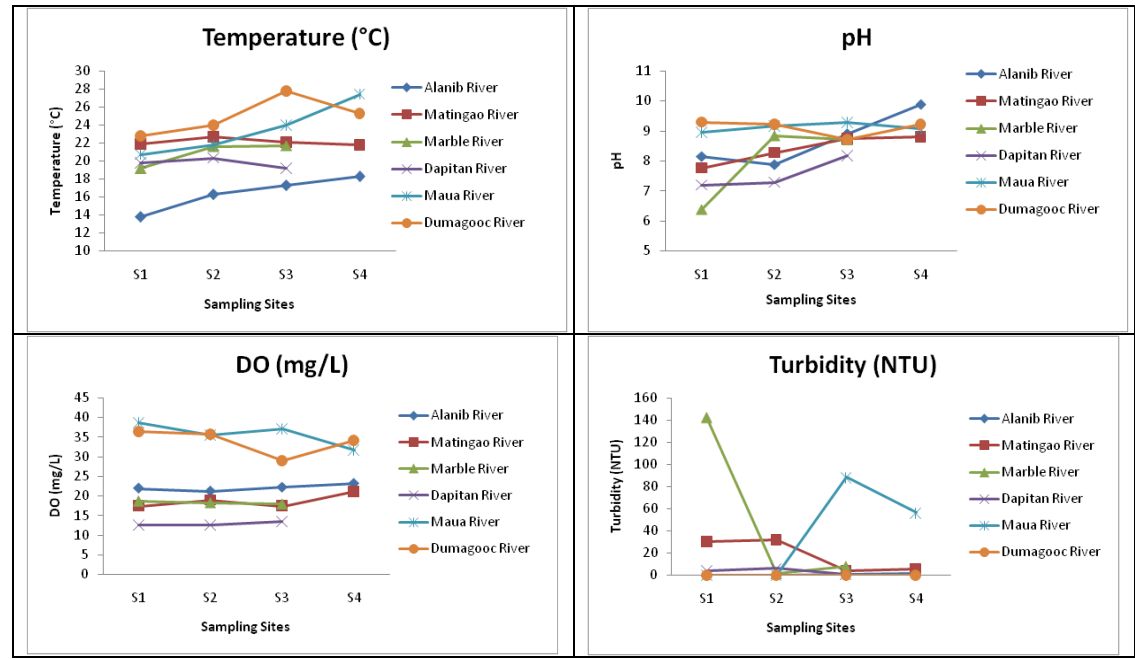

Figure 7. Measured water qualities of five Mindanao LTER sites

\section{CONCLUSIONS}

The freshwater fish in Mindanao LTER sites is highly diverse. These sites support one endemic species, ten native species and fifteen introduced species. Based on the results of the study, Mt. Hamiguitan had the most number of individual fish counts followed by Mt. Musuan and Mt. Apo, Mt. Malindang, 
and Mt. Kitanglad. The commonly occurring fish in all sampling sites were Cyprinids mainly the Puntius binutatus and P. bantolanensis. Mt. Kitanglad has the least similar species compared to the other four mountains based on Bray- Curtis Cluster Analysis while the most diverse species of fish was found in Mt. Hamiguitan, followed by Mt. Musuan, Mt. Malindang, Mt. Apo, and Mt. Kitanglad based on Shannon Diversity Index. Temperature, pH, DO and Turbidity affected the presence of fishes in some selected sites as due to various anthropogenic activities. The presence of introduced species could be a threat to native and endemic species in the studied aquatic ecosystems.In addition, the presence of geothermal power plant, increasing human population and activity and agricultural intensification at the vicinity of Marble and Matingao Rivers at Mt. Apo which have contributed to their relatively low water quality as compared to Dapitan River in Mt. Malindang and the upstream and midstream of Alanib River at Mt. Kitanglad which are dominated by forests and with minimal human and agricultural activities. Therefore, community awareness as well as policy formulation regarding the protection and conservation of the biological resources of the aquatic ecosystems in Mindanao LTER sites should be established and implemented.

\section{ACKNOWLEDGMENTS}

The authors would like to express our sincerest gratitude to the Commission on Higher Education (CHED) under the auspices of the Office for Policies,Planning, Research and Information (OPPRI) for funding the research project. Thanks are also due to the administration of CMU, Center for Biodiversity Research and Extension in Mindanao (CEBREM) and the local researchers namely; Benjo Logramonte, Gerald S. Opiso and Verne Lloyd Calunsag for their assistance, support and in helping us in the data collection. Lastly, this project would not be possible without the permit from DENR and Protected Area Management Board (PAMB) and the support of the local community in the study area.

\section{LITERATURE CITED}

Alabaster, S.S. and Lloyd, R.

1980 Water quality criteria for freshwater fish. European Inland Fisheries Advisory Commission Report(FAO). Buttersworth, LondonBoston.297 pp. 
BioDiveristy Professional version 2.

1997 Natural History Museum and The Scottish Association for Marine Science.

Bryan, $\mathrm{M}$.

2004 pH Requirements of Freshwater Aquatic Life.

Robertson-bryan.Inc. 15 pp.

Ellis, M.M.

1937 Detection and measurement of stream pollution.Bul.U.S. Bureau of Fisheries. 58:365-437.

Fishbase.

2013 FishBase: a biological database on fish version 8. CD-ROM. Manila: International Center for Living Aquatic Resources Management.

$\mathrm{He}, \mathrm{Y}$.

2010 Structure of endemic fish assemblages in the upper Yangtze River basin and population differentiation of an endangered endemic fish (Gobio cyprisrarus).PhD Thesis, Institute of Hydrobiology (Wuhan).191 pp.

Jackson, S.D.

2003 Ecological Considerations in the Design of River and Stream Crossings.Proceedings of the International Conference in Ecology and Transportation, North Carolina State University.10 pp.

Joshi, R.C.

(2007) Invasive Alien Species (IAS).Concerns and Status in the Philippines. Accessed on Dec. 6,2013.

Khan, A.M., Ali, Z., Shelly, S.Y., Ahmad, Z., and Mirza, M.R.

2011 Aliens: a catastrophe for native freswater fish diversity in pakistan. The Journal of Animal and Plant Science.p 435-440. 
Kausar, R. and M. Salim

2006 Effect of Water Temperature on the Growth Performance and Feed Conversion Ratio of LabeoRohita. Department of Zoology and Fisheries, University of Agriculture, Faisalabad, Pakistan.

Leveque, C., Oberdorff, T., Paugy, D., Stiassny, M.L.J., and Tedesco, P.A.

2008 Global diversity of fish (Pisces) in freshwater. Hydrobiologia.595: 545567.

Marín, E.J.

2013 Ecological models at fish community and species level to support effective river restoration. $\mathrm{PhD}$ Thesis, UniversitatPolitècnica de València, Spain. 175 pp.

Miller, P.

1986 The endurance of endemism; The Mediterranean freshwater gobies and their prospects for survival.Journal of Fish Biology 37A (Suppl.) 14556.

Myers, N., R.A Mittermier, C.G. Mittermeier, G.A.B DA Fonseca and J. Kent. 2000 Biodiversity Hotspots for Conservation Priorities. Green College, Oxford University, Upper Meadow, Old Road, Headington, Oxford OX3 8SZ,UK. Conservation International 2501 M Street NW, Washington, DC20037, USA. Centre for Applied Biodiversity Science, Conservation International $2501 \mathrm{M}$ Street NW, Washington, DC 20037, USA. 35 Dorchester Close, Headington, Oxford OX3 8SS, UK.

Nduka, A., Moses, N., and Shirima, M.

2012 The impact of nitrate on water due to the application of fertilizers. DIOCEST OF MOSHI, KIBOSHO.

Tweedley, J.R., Bird, D.J., Potter, I.C., Gill, H.S., Miller., P.J., O’donovan, G., and Tjakrawidjaja, A.H.

2013 Species composition and ecology of the riverine ichthyofaunas in two Sulawesian Islands in the biodiversity hotspot of Wallacea.Journal of Fish Biology. 82: 1916-1950 pp. 


\section{Plate 1. Fish Species Composition in Five LTER Sites in Mindanao, Philippines}

\begin{tabular}{|c|c|c|c|}
\hline$(8$ & $\begin{array}{c}\text { Anabanthidae } \\
\text { Anabas testudineus } \\
\text { (Bloch, 1792) } \\
\text { Climbing Perch } \\
\text { Puyo } \\
\text { Mt. Musuan }\end{array}$ & 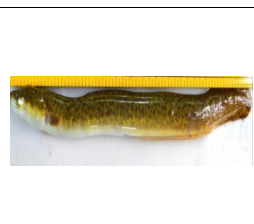 & $\begin{array}{c}\text { Anguillidae } \\
\text { Anguilla marmorata } \\
\text { (Quoy\&Gaimard, 1842) } \\
\text { Freshwater molted eel } \\
\text { Kasili } \\
\text { Mt. Hamiguitan } \\
\text { Mt. Malindang }\end{array}$ \\
\hline & $\begin{array}{c}\text { Cichilidae } \\
\text { Oreochromis aureus } \\
\text { (Steindachner, 1864) } \\
\text { Tilapia } \\
\text { Mt. Musuan }\end{array}$ & & $\begin{array}{c}\text { Clariidae } \\
\text { Clarias gariepinus } \\
\text { (Burchell, 1822) } \\
\text { North African Catfish } \\
\text { Taiwan hito } \\
\text { Mt. Musuan }\end{array}$ \\
\hline 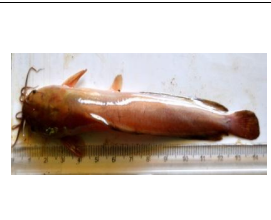 & $\begin{array}{c}\text { Clariidae } \\
\text { Clarias sp. } \\
\text { North African Catfish } \\
\text { Taiwan hito } \\
\text { Mt. Musuan }\end{array}$ & & $\begin{array}{c}\text { Cyprinidae } \\
\text { Chagunius chagonio } \\
\text { (Hamilton, 1822) } \\
\text { Carp } \\
\text { Karpa } \\
\text { Mt. Musuan } \\
\text { Mt. Hamiguitan }\end{array}$ \\
\hline 0 & $\begin{array}{c}\text { Cyprinidae } \\
\text { Cyprinus carpio carpio } \\
\text { (Linnaueus, 1778) } \\
\text { Common Carp } \\
\text { Karpa } \\
\text { Mt. Musuan } \\
\text { Mt. Malindang }\end{array}$ & & $\begin{array}{c}\text { Cyprinidae } \\
\text { Puntius bantolanensis } \\
\text { (Day 1914) } \\
\text { Barb } \\
\text { Pait/Paitan } \\
\text { Mt. Apo } \\
\text { Mt. Hamiguitan }\end{array}$ \\
\hline
\end{tabular}




\begin{tabular}{|c|c|c|c|}
\hline & $\begin{array}{c}\text { Cyprinidae } \\
\text { Puntius binotatus } \\
\text { (Valenciennes, 1842) } \\
\text { Spotted barb } \\
\text { Pait/Paitan } \\
\text { Mt. Apo } \\
\text { Mt. Hamiguitan } \\
\text { Mt. Malindang } \\
\text { Mt. Musuan } \\
\text { Mt. Kitanglad }\end{array}$ & & $\begin{array}{l}\text { Eleotridae } \\
\text { Allomogurnda sp. } \\
\text { Gurdeon } \\
\text { Borod } \\
\text { Mt. Hamiguitan }\end{array}$ \\
\hline & $\begin{array}{c}\text { Eleotridae } \\
\text { Butis sp. } \\
\text { Sleeper/Gurdeon } \\
\quad \text { Mokong } \\
\\
\text { Mt. Hamiguitan }\end{array}$ & & $\begin{array}{l}\text { Eleotridae } \\
\text { Oxyeleotris sp. } \\
\text { Sleepy Cod } \\
\quad \text { Borod } \\
\text { Mt. Hamiguitan }\end{array}$ \\
\hline & $\begin{array}{c}\text { Eleotridae } \\
\text { Oxyeleotris sp.2 } \\
\text { Sleepy Cod } \\
\quad \text { Borod } \\
\\
\text { Mt. Hamiguitan }\end{array}$ & 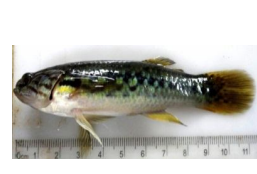 & $\begin{array}{l}\text { Eleotridae } \\
\text { Mogurnda sp. } \\
\text { Trout Gurdeon } \\
\text { Bibangon } \\
\text { Mt. Hamiguitan }\end{array}$ \\
\hline 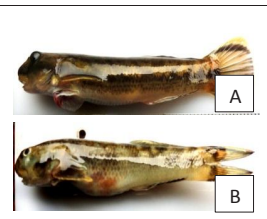 & $\begin{array}{c}\text { Gobiidae } \\
\text { Sicyopterus lagocephalus } \\
\text { (Pallas, 1770) } \\
\text { Red-tailed Goby } \\
\text { A .Round tailed } \\
\text { B. fork tailed } \\
\text { Sahognon/Balulo } \\
\text { Mt. Hamiguitan }\end{array}$ & & $\begin{array}{c}\text { Gobiidae } \\
\text { Sicyopterus micrurus } \\
\text { (Pallas, 1770) } \\
\text { Cobalt Blue/Clinging } \\
\text { Goby } \\
\text { Sahognon/Balulo } \\
\text { Mt. Hamiguitan } \\
\text { Mt. Kitanglad }\end{array}$ \\
\hline & $\begin{array}{c}\text { Gobiidae } \\
\text { Stiphodonatro purpureus } \\
\text { (Herre, 1927) } \\
\text { Blue Neon Goby } \\
\text { Sahognon/Balulo } \\
\\
\text { Mt. Hamiguitan }\end{array}$ & 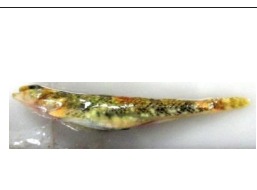 & $\begin{array}{c}\text { Gobiidae } \\
\text { Unidentified } \\
\text { Mt. Hamiguitan }\end{array}$ \\
\hline
\end{tabular}




\begin{tabular}{|c|c|c|c|}
\hline eforits & $\begin{array}{c}\text { Gobiidae } \\
\text { Unidentified } \\
\text { Mt. Hamiguitan }\end{array}$ & 3 & $\begin{array}{c}\text { Gobiidae } \\
\text { Unidentified } \\
\text { Mt. Apo }\end{array}$ \\
\hline & $\begin{array}{l}\text { Loricarridae } \\
\text { Pterygoplichthys } \\
\text { disjunctivus } \\
\text { (Weber, 1991) } \\
\text { Janitor Fish } \\
\text { Mt. Musuan }\end{array}$ & $\frac{1}{y}$ & $\begin{array}{c}\text { Ophicephalidae } \\
\text { Ophicephalus striatus } \\
\text { (Bloch, 1793) } \\
\text { Striated murrel } \\
\text { Haluan } \\
\text { Mt. Musuan }\end{array}$ \\
\hline & $\begin{array}{c}\text { Ophichthidae } \\
\text { Ophichthus apicalis } \\
\text { (Bennett, 1830) } \\
\text { Blunt nose snake eel } \\
\text { Kasili } \\
\text { Mt. Hamiguitan }\end{array}$ & & $\begin{array}{c}\text { Osphronomidae } \\
\text { Trichogaster } \\
\text { trichopterus } \\
\text { (Pallas, 1770) } \\
\text { Three spot gourami } \\
\text { Gourami } \\
\text { Mt. Musuan }\end{array}$ \\
\hline & $\begin{array}{l}\text { Osphronomidae } \\
\text { Trichogaster sp. } \\
\quad \text { Gourami } \\
\text { Mt. Musuan }\end{array}$ & & $\begin{array}{c}\text { Poeciliidae } \\
\text { Gambusia affinis (Baird } \\
\text { \& Girard, 1853) } \\
\text { Guppy } \\
\text { Butiti/Buriring } \\
\text { Mt. Malindang } \\
\text { Mt. Musuan } \\
\text { Mt. Apo }\end{array}$ \\
\hline & $\begin{array}{c}\text { Poeciliidae } \\
\text { Poecilia sp. } \\
\text { Guppy } \\
\text { Buriring } \\
\text { Mt. Apo } \\
\text { Mt. Malindang }\end{array}$ & $\frac{11}{B}$ & $\begin{array}{c}\text { Poeciliidae } \\
\text { Xiphophorus helerii } \\
\text { (Heckel, 1848) } \\
\text { Swordtail fish } \\
\text { A. Female } \\
\text { B. Male } \\
\text { Mt. Apo } \\
\text { Mt. Malindang }\end{array}$ \\
\hline
\end{tabular}




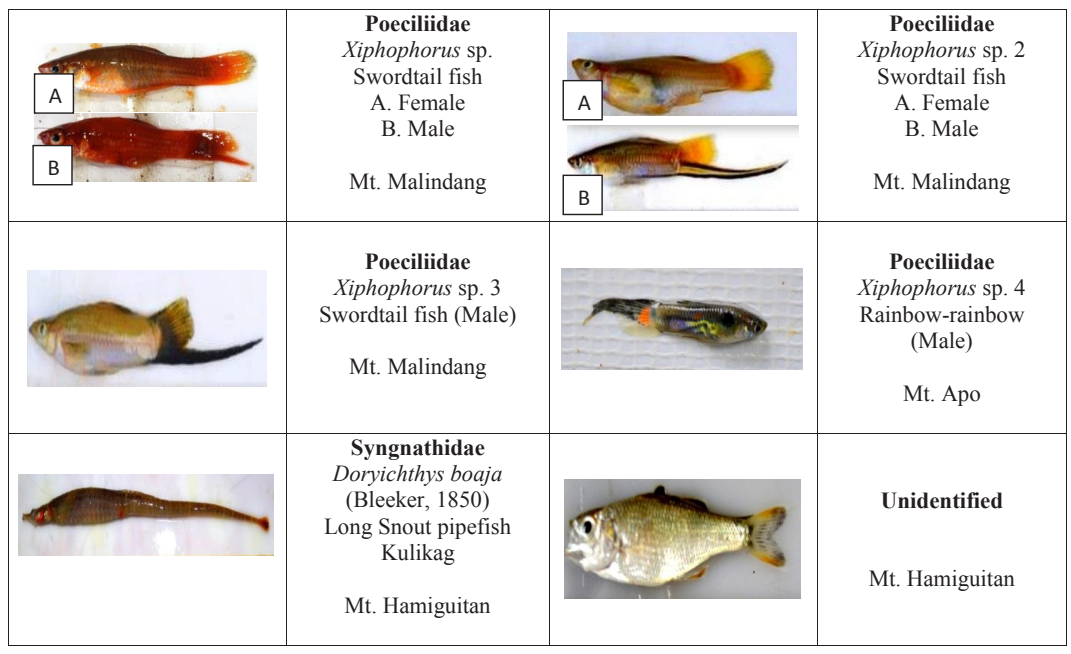

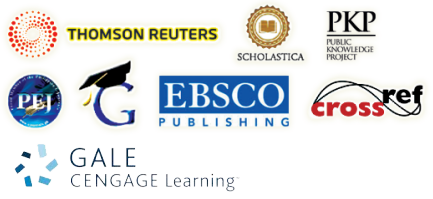

